JOURNAL OF MECHANICAL ENGINEERING, MANUFACTURES, MATERIALS AND ENERGY

Doi: $10.31289 /$ jmemme.v5i2.4630

Available online http://ojs.uma.ac.id/index.php/jmemme

\title{
Pengaruh Temperatur Artificial Age Terhadap Kekerasan, Kekuatan luluh, dan Kerapatan Dislokasi pada Paduan $\mathrm{Al}_{97,11} \mathbf{M g}_{1,52} \mathrm{Si}_{0,86} \mathbf{Z n}_{0,51}$
}

\section{Effect of Artificial Age Temperature on Hardness, Yellow Strength, and Dislocation Density of $\mathrm{Al}_{97,11} \mathrm{Mg}_{1,52} \mathrm{Si}_{0,86} \mathrm{Zn}_{0,51}$ Alloy}

\author{
Budiarto Djono Siswanto* \\ Program Studi Teknik Mesin, Fakultas Teknik, Universitas Kristen Indonesia
}

Diterima: 18-12-2020 ; Disetujui: 30-07-2021 ; Diterbitkan: 30-12-2021

*Corresponding author: E-mail: budidamaz@gmail.com

\begin{abstract}
ABSTRAK
Telah dilakukan penelitian pengaruh temperatur artificial age terhadap kekerasan, kekuatan luluh, dan kerapatan dislokasi pada paduan $\mathrm{Al}_{97,11} \mathrm{Mg}_{1,52} \mathrm{Si}_{0,86} \mathrm{Zn}_{0,51}$. Sampel paduan $\mathrm{Al}_{97,11} \mathrm{Mg}_{1,52} \mathrm{Si}_{0,86} \mathrm{Zn}_{0,51}$ ini dibuat dengan metalurgi butiran selanjutnya dilakukan pemanasan T6 ( pemanasan solid solution pada temperatur $5300^{\circ} \mathrm{C}$ selama 1 jam dan variasi temperatur artificial age $140^{\circ} \mathrm{C}, 170^{\circ} \mathrm{C}$, dan $200^{\circ} \mathrm{C}$ serta waktu selama 1 jam. Hasil pengujian kekerasan menunjukkan bahwa paduan $\mathrm{Al}_{97,11} \mathrm{Mg}_{1,52} \mathrm{Si}_{0,86} \mathrm{Zn}_{0,51}$ kekerasan naik akibat adanya variasi temperatur artificial age. Pengamatan struktur mikro menunjukkan struktur hypoeutektik terdiri dari dendrit aluminium primer dan campuran eutektik paduan $\mathrm{Al}_{97,11} \mathrm{Mg}_{1,52} \mathrm{Si}_{0,86} \mathrm{Zn}_{0,51}$. Hasil analisa kerapatan dislokasi, regangan mikro, dan ukuran kristal setelah perlakuan panas T6 menunjukkan bahwa paduan $\mathrm{Al}_{97,11} \mathrm{Mg}_{1,52} \mathrm{Si}_{0,86} \mathrm{Zn}_{0,51}$. terdiri dari fasa $\alpha$ - $\mathrm{Al}$, dan fasa $\mathrm{Mg}_{2} \mathrm{Si}$.Hasil artificial age mengakibatkan terjadinya rekristalisasi dan pertumbuhan butir yang terbukti dengan naiknya regangan mikro dari 25,05\% menjadi 32,83\% pada bidang indeks Miller (311), naiknya ukuran kristalit dari $7,6734 \mathrm{~nm}$ menjadi $21,3354 \mathrm{~nm}$, turunnya kerapatan dislokasi dari $0,06241 / \mathrm{m}^{2}$ menjadi $0.00671 / \mathrm{mm}^{2}$ dan turunnya kekuatan luluh dari 573,54 MPa menjadi 312,65 MPa.

Kata kunci: Paduan $\mathrm{Al}_{97,11} \mathrm{Mg}_{1,52} \mathrm{Si}_{0,86} \mathrm{Zn}_{0,51}$, kerapatan dislokasi, kekerasan, XRD.
\end{abstract}

\section{ABSTRACT}

The dislocation density, micro lattice strain, crystal size, microstructure and hardness of T6 heating treatment have been carried out with variations in temperature of artificial age in Al97,11Mg1,52Sio,86Zno,51 alloys. The Al97,11 Mg1,52Sio,86Zno,51 alloy sample was made with granular metallurgy and then T6 was heated (solid solution heating at 530 OC for 1 hour and temperature variations of artificial age 1400C,1700C, and 2000C and time for 1 hour). The hardness test results showed that the $\mathrm{Al}_{97,11} \mathrm{Mg}_{1,52} \mathrm{Si}_{0,86} \mathrm{Zn}_{0,51}$ alloy increased due to variations in artificial age temperatures. Microstructure observation shows hypoeutectic structure consisting of primary aluminum dendrite and

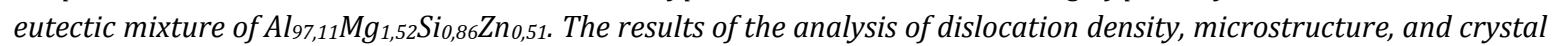
size after T6 heat treatment showed that the Al97,11 Mg1,52Sio,86Zno,51 alloy. consists of the ?-Al phase, and the Mg2Si phase. The results of artificial age resulted in recrystallization and grain growth as evidenced by an increase in microstrain from $25.05 \%$ to $32.83 \%$ in the Miller index (311), an increase in crystallite size from $7.6734 \mathrm{~nm}$ to $21.3354 \mathrm{~nm}$, and a decrease in dislocation density. from $0.06241 / \mathrm{mm}^{2}$ to $0.00671 / \mathrm{mm}^{2}$ and a decrease in yield strength from 573.54 MPa to 312.65 Mpa.

Keywords: $A l_{97,11} \mathrm{Mg}_{1,52} \mathrm{Si}_{0,86} \mathrm{Zn}_{0,51}$ Alloys, dislocation density, hardness, XRD 
How to Cite:, Siswanto, B.D., Pengaruh Temperatur Artificial Age Terhadap Kekerasan, Kekuatan luluh Dan Kerapatan Dislokasi Pada Paduan $\mathrm{Al}_{97,11} \mathrm{Mg}_{1,52} \mathrm{Si}_{0,86} \mathrm{Zn}_{0,51}$, JMEMME (Journal of Mechanical Engineering, Manufactures, Materials and Energy), 5 (2): 115 - 133 
Budiarto Djono Siswanto, Pengaruh Temperatur Artificial Age Terhadap Kekerasan ...

\section{PENDAHULUAN}

Aluminium adalah logam yang ringan dan cukup penting dalam kehidupan manusia. Aluminium merupakan unsur kimia golongan IIIA dalam sistim periodik unsur, dengan nomor atom 13 dan berat atom 26,98 gram per mol (sma) [1]. Struktur kristal aluminium adalah struktur kristal FCC, sehingga aluminium tetap ulet meskipun pada temperatur yang sangat rendah. Keuletan yang tinggi dari aluminium menyebabkan logam tersebut mudah dibentuk atau mempunyai sifat mampu bentuk yang baik [1]. Aluminium memiliki beberapa kekurangan yaitu kekuatan dan kekerasan yang rendah bila dibanding dengan logam lain seperti besi. Juga aluminium merupakan logam ringan yang mempunyai ketahanan korosi yang baik dan hantaran listrik yang baik dan sifat-sifat yang baik lainnya sebagai sifat logam. Sebagai tambahan terhadap, kekuatan mekaniknya yang sangat meningkat dengan penambahan $\mathrm{Cu}, \mathrm{Mg}, \mathrm{Si}, \mathrm{Mn}, \mathrm{Zn}, \mathrm{Ni}$, dsb. Secara satu persatu atau bersama-sama, memberikan juga sifat-sifat baik lainnya seperti ketahanan korosi, ketahanan aus, koefisien pemuaian rendah. Material ini dipergunakan di dalam bidang yang luas bukan saja untuk peralatan rumah tangga tapi juga dipakai untuk keperluan material pesawat terbang, mobil, kapal laut, konstruksi [1]. Aluminium memiliki karakteristik sebagai logam ringan dengan kerapatan 2,7 g/ $\mathrm{cm}^{3}$ [1].

Sifat tahan korosi pada aluminium diperoleh karena terbentuknya lapisan oksida aluminium pada permukaaan aluminium. Memadukan aluminium dengan unsur lainnya merupakan salah satu cara untuk memperbaiki sifat aluminium tersebut.

Paduan adalah kombinasi dua atau lebih jenis logam, kombinasi ini dapat merupakan campuran dari dua struktur kristalin. Paduan dapat disebut juga sebagai larutan padat dalam logam. Larutan padat mudah terbentuk bila pelarut dan atom yang larut memiliki ukuran yang sama dan strukrur elektron yang serupa. Larutan dalam logam utama tersebut memiliki batas kelarutan maksimum. Paduan yang masih dalam batas kelarutan disebut dengan paduan logam fasa tunggal. Sedangkan paduan yang melebihi batas kelarutan disebut dengan fasa ganda. Peningkatan kekuatan dan kekerasan logam paduan disebabkan oleh adanya atom-atom yang larut yang menghambat pergerakan dislokasi dalam kristal sewaktu deformasi plastik [1]. Secara garis besar paduan aluminium dibedakan menjadi dua jenis yaitu paduan aluminium tempa dan aluminium cor.

Sifat-sifat umum pada paduan aluminium adalah: 
a. Jenis Al-murni teknik (seri 1xxx)

Jenis paduan ini mempunyai kandungan minimal aluminium 99,0\% dengan besi dan silikon menjadi kotoran utama (elemen paduan). Aluminium dalam seri ini memiliki kekuatan yang rendah tapi memiliki sifat tahan korosi, konduksi panas dan konduksi listrik yang baik juga memiliki sifat mampu las dan mampu potong yang bagus. Aluminium seri ini banyak digunakan untuk sheet metal work.

b. Paduan Al-Cu (seri 2xxx)

Elemen paduan utama pada seri ini adalah tembaga, tetapi magnesium dan sejumlah kecil elemen lain juga ditambahkan kesebagian besar paduan jenis ini. Jenis paduan Al-Cu adalah jenis yang dapat diperlaku-panaskan. Dengan melalui pengerasan endap atau penyepuhan, sifat mekanikpaduan ini dapat menyamai sifat dari baja lunak, tetapi daya tahan korosinya rendah bila dibandingkan dengan jenis paduan yang lainnya. Sifat mampu lasnya juga kurang baik, karena itu paduan jenis ini biasanya digunakan pada kontruksi keling dan banyak sekali digunakan dalam kontruksi pesawat terbang seperti duralumin dan super duralumin.

c. Paduan jenis Al-Mn (seri 3xxx)

Manganesee merupakan elemen paduan utama seri ini. Paduan ini adalah jenis yang tidak dapat diperlaku-panaskan, sehingga penaikan kekuatannya hanya dapat diusahakan melalui pengerjaan dingin pada proses pembuatannya. Bila dibandingkan dengan jenis alumunium murni, paduan ini mempunyai sifat yang sama dalam hal ketahanan terhadap korosi, mampu potong dan sifat mampu lasnya, sedangkan dalam hal kekuatannya, jenis paduan ini jauh lebih unggul.

d. Paduan jenis Al-Si (seri 4xxx)

Paduan Al-Si termasuk jenis yang tidak dapat diperlaku-panaskan. Jenis ini dalam keadaaan cair mempunyai sifat mampu alir yang baik dan dalam proses pembekuannya hampir tidak terjadi retak. Karena sifat-sifatnya, maka paduan jenis Al-Si banyak digunakan sebagai bahan atau logam las dalam pengelasan paduan aluminium baik paduan cor atau tempa.

e. Paduan jenis Al-Mg (seri 5xxx)

Magnesium merupakan paduan utama dari komposisi sekitar 5\%. Jenis ini mempunyai sifat yang baik dalam daya tahan korosi, terutama korosi oleh air laut dan 
sifat mampu lasnya. Paduan ini juga digunakan untuk sheet metal work, biasanya digunakan untuk komponen bus, truk, dan untuk aplikasi kelautan.

f. Paduan jenis Al-Mg-Si (seri 6xxx)

Elemen paduan seri 6xxx adalah magnesium dan silicon. Paduan ini termasuk dalam jenis yang dapat diperlaku-panaskan dan mempunyai sifat mampu potong dan daya tahan korosi yang cukup. Sifat yang kurang baik dari paduan ini adalah terjadinya pelunakan pada daerah las sebagai akibat dari panas pengelasan yang timbul. Paduan jenis ini banyak digunakan untuk tujuan struktur rangka.

g. Paduan jenis Al-Zn (seri 7xxx)

Paduan ini termasuk jenis yang dapat diperlaku-panaskan. Biasanya ke dalam paduan pokok Al-Zn ditambahkan Mg, Cu dan Cr. Kekuatan tarik yang dapat dicapai lebih dari $504 \mathrm{Mpa}$, sehingga paduan ini dinamakan juga ultra duralumin yang sering digunakan untuk struktur rangka pesawat. Berlawanan dengan kekuatan tariknya, sifat mampu las dan daya tahannya terhadap korosi kurang menguntungkan. Akhir-akhir ini paduan Al-Zn-Mg mulai banyak digunakan dalam kontruksi las, karena jenis ini mempunyai sifat mampu las dan daya tahan korosi yang lebih baik daripada paduan dasar Al-Zn [1].

Proses kondisi padat bisa dilakukan dengan salah satu cara yaitu dengan metalurgi serbuk. Metalurgi serbuk merupakan suatu proses pembuatan serbuk dan benda jadi dari serbuk logam atau paduan logam dengan ukuran serbuk tertentu tanpa melalui proses peleburan. Tahapan dari proses metalurgi serbuk secara umum dibagi menjadi 3(tiga) bagian, yaitu pencampuran serbuk matriks dan penguat (mixing), penekanan, dan pemanasan (sintering) pada temperatur tinggi. Teknik pembuatan dengan metalurgi serbuk memiliki kelebihan dibanding proses lainnya, diantaranya adalah diperoleh distribusi partikel penguat lebih merata dan sifat mekanik yang lebih baik, produk lebih beraneka ragam dan temperatur proses lebih rendah. Sedangkan kekurangan dari proses metalurgi serbuk dibandingkan teknik pengecoran adalah biaya relatif lebih mahal, ukuran benda yang dibuat terbatas dan dihasilkan produk dengan porositas lebih tinggi $[2,3]$.

Penelitian oleh Putri, dkk (2020) pada paduan Al- 7075 dimana nilai kekerasan maksimum dicapai pada suhu artificial aging $200{ }^{\circ} \mathrm{C}$ dengan holding time 1 jam sebesar 
23,035 HBN [4]. Namun pada sampel material paduan Al 7075 setelah penuaan buatan dari waktu tahan 1 jam dibandingkan waktu tahan 24 jam dam 30 jam terjadi penurunan kekerasan sebesar 17,93\% dan 14,58\%. Disebabkan adanya over age. Pengujian komposisi unsur kimia menunjukkan unsur yang terkandung antara lain $\mathrm{Al}, \mathrm{Mg}, \mathrm{Si}, \mathrm{Zn}$. Ukuran kristal terbesar pada bidang indeks Miller ( $\left.\begin{array}{lll}2 & 0 & 0\end{array}\right)$ terjadi pada perlakuan panas artificial aging pada suhu $200{ }^{\circ} \mathrm{C}$ holding time 30 jam sebesar 23,94550 nm. Ukuran kristal terkecilnya terjadi pada perlakuan panas artificial aging pada suhu $200{ }^{\circ} \mathrm{C}$ holding time 24 jam sebesar 3,4405 nm. Hasil penelitian tersebut juga diperkuat oleh Megantara dkk (2020) yang menyimpulkan bahwa pada hasil pengujian struktur mikro dengan SEM, terdapat perbedaan antara sampel uji Al 5052 tanpa dan dengan perlakuan panas yang jelas [5]. Terlihat sampel uji Al 5052 tanpa perlakuan panas matriks Al yang dominan, sedangkan pada sampel uji Al 5052 setelah melalui proses T6 memunculkan fasa MgZn2 yang mengakibatkan nilai kekerasan (sifat mekanik) meningkat secara signifikan. Hal ini menunjukkan bahwa penambahan kadar Mg dalam jumlah yang besar pada paduan Alumunium juga dapat menaikkan kekuatan tarik. Demikian juga hasil pengujian ukuran kristal, kerapatan dislokasi, dan regangan kisi mikro dengan X-Ray Diffraction (XRD), menunjukkan bertambahnya ukuran kristal seiring dengan lamanya waktu pemanasan penuaan buatan $[6,7,8]$.

Melihat prospek kedepan aplikasi perlakuan panas T6 sebagai metode yang dapat digunakan untuk mendapatkan material dengan kombinasi sifat-sifat yang lebih baik dan dapat diterapkan pada hampir semua kelompok paduan aluminium pengerasan presipitat, atau bahkan paduan pengerasan presipitat pada umumnya dan melihat sampai sejauh ini di Indonesia perlakuan tersebut sudah banyak mendapat perhatian, maka penelitian yang dilakukan untuk mengetahui pengaruh variasi temperatur artificial age (artificially age) terhadap kerapatan dislokasi, regangan mikro kisi dan ukuran kristal dan sifat mekanik serta strukturmikronya $[9,10]$. Manfaat lainnya adalah mendapat pemahaman yang lebih baik mengenai pembuatan paduan alumunium metode metalurgi butiran, proses T6 dan pertumbuhan presipitat serta hubungannya dengan sifat material yang dihasilkan sehingga diperoleh material dengan sifat-sifat yang diinginkan [11].

Proses perlakuan panas T6 terhadap paduan Aluminium dilakukan melalui metode pengerasan dengan terbentuk endapan (Precipitation hardening) yang secara garis besar terdiri dari tiga langkah.Langkah pertama, perlakuan panas pelarutan (solution heat 
treatment), langkah kedua, pendinginan cepat (quenching) untuk mendapatkan larutan lewat jenuh (supersaturated) dan langkah ketiga: Proses penuaan buatan (artifical aging)

Pengujian struktur kristal seperti ukuran kristal, kerapatan dislokasi, dan mikro regangan kisi paduan $\mathrm{Al}_{97,11} \mathrm{Mg}_{1,52} \mathrm{Si}_{0,86} \mathrm{Zn}_{0,51}$ menggunakan alat Difraktometer sinar-X (XRD) dengan sumber radiasi $\mathrm{Cu} \operatorname{K} \alpha(\lambda=1,5406 \AA$ A). Data XRD diperoleh pada temperatur ruang dengan rentang dari $25^{\circ}$ sampai $100^{\circ}$ menggunakan kecepatan scan $2 \%$ min dan lebar step $0,02^{\circ}$. Parameter kristal seperti, rata-rata ukuran kristal, regangan mikro kisi, kerapatan dislokasi, dan parameter kisi (a dan c) ditentukan dari hasil analisis XRD. Ratarata ukuran kristal (D) dari paduan $\mathrm{Al}_{97,11} \mathrm{Mg}_{1,52} \mathrm{Si}_{0,86} \mathrm{Zn}_{0,51}$. diestimasi dengan menggunakan persamaan Derby Scherrer $[3,12]$.

$$
\mathrm{D}=0,9 \lambda / \beta \cos \theta
$$

dimana, $\lambda$ adalah panjang gelombang sinar-x $(1,5405 \AA$ ), $\beta$ adalah FWHM (full width at half maximum) dari puncak (hkl) dan $\theta$ adalah sudut difraksi. Regangan mikro kisi $(\varepsilon)$ dihitung menggunakan persamaan (2) [12].

$$
\varepsilon=\beta / 4 \tan \theta
$$

Kerapatan dislokasi $(\rho)$ karena regangan kisi dapat dinyatakan dengan hubungan persamaan (3) [12].

$$
\rho=1 / D^{2}
$$

Setelah kerapatan dislokasi diketahui, maka kekuatan luluh (Ys) dapat dihitung dengan persamaan (4) [13].

$$
Y s=274,54+4,963 \times 10^{-6} \sqrt{\rho}
$$

dengan satuan Ys dalam MPa dan $\rho$ dalam $\mathrm{m} / \mathrm{m}^{3}$ atau garis $/ \mathrm{m}^{2}$.

Penelitian ini bertujuan untuk mempelajari proses T6 mulai solid solution treatment temperatur $530^{\circ} \mathrm{C}$ selama 1 jam dan pengaruh variasi temperatur artificially age 140, 170 dan $200^{\circ} \mathrm{C}$ waktu tahan 1 jam dari paduan $\mathrm{Al}_{97,11} \mathrm{Mg}_{1,52} \mathrm{Si}_{0,86} \mathrm{Zn}_{0,51}$ yang dibuat dengan 
metode metalurgi serbuk untuk bahan roket, kemudian dilakukan uji kekerasan, kerapatan dislokasi, regangan mikro kisi, ukuran kristal dan pengamatan struktur mikro.

\section{METODE PENELITIAN}

Bahan yang digunakan pada penelitian ini adalah paduan $\mathrm{Al}_{97,11} \mathrm{Mg}_{1,52} \mathrm{Si}_{0,86} \mathrm{Zn}_{0,51}$ yang dibuat dengan metalurgi serbuk. Pembuatan dimulai dengan menimbang sernuk $\mathrm{Al}$, Mg, Si, Zn dan mencampur ke empat serbuk Al, Mg, Si, dan Zn. Kemudian dicetak pada dies dan ditekan 20 Ton serta di sinter temperatur $475{ }^{\circ} \mathrm{C}$. Ukuran dies diameter $20 \mathrm{~mm}$, tebal $2 \mathrm{~mm}$. Selanjutnya dilakukan perlakuan panas T6 (solid solution pada temperatur $530^{\circ} \mathrm{C}$ selama 1 jam dan proses artificial age dengan waktu tahan tetap 1 jam dan variasi temperatur $140^{\circ} \mathrm{C}, 170^{\circ} \mathrm{C}$, dan $200^{\circ} \mathrm{C}$ ).

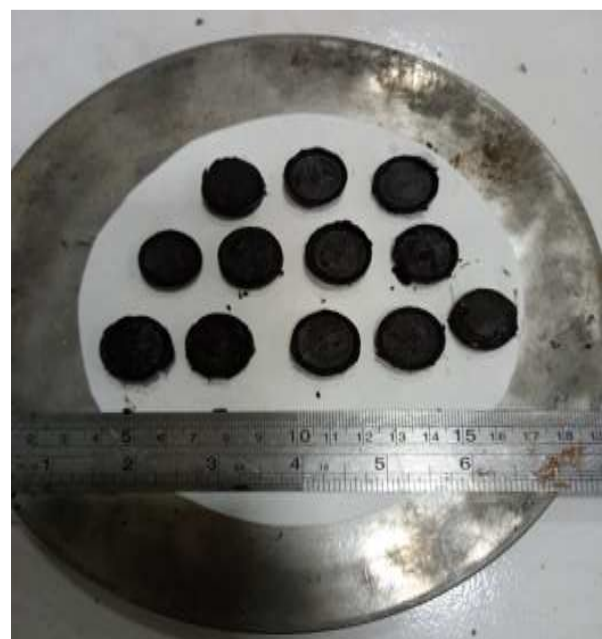

Gambar 1. Sampel paduan $\mathrm{Al}_{97,11} \mathrm{Mg}_{1,52} \mathrm{Si}_{0,86} \mathrm{Zn}_{0,51}$

Tabel 1. Data hasil uji komposisi unsur kimia paduan $\mathrm{Al}_{97,11} \mathrm{Mg}_{1,52} \mathrm{Si}_{0,86} \mathrm{Zn}_{0,51}$ dengan alat OE Spektrometer

\begin{tabular}{ccccccccccc}
\hline Unsur & Al & Si & Mg & Cu & Mn & Zn & Fe & Pb & Cr & Ti \\
\hline Wt\% & 97,11 & 0,86 & 1,52 & 0,018 & 0,002 & 0,51 & 0,005 & 0,001 & 0,003 & 0,002
\end{tabular}

Selanjutnya sampel paduan $\mathrm{Al}_{97,11} \mathrm{Mg}_{1,52} \mathrm{Si}_{0,86} \mathrm{Zn}_{0,51}$ dilakukan pengujian kerapatan dislokasi, regangan mikro kisi, ukuran kristal, dan struktur kristal dengan alat difraktometer sinar-X (XRD) seperti diperlihatkan pada gambar 3. Pengujian terhadap kekerasan dengan skala mikro Vickers menggunakan alat mikro Vickers seperti diperlihatkan pada gambar 4, serta pengamatan struktur mikro dengan menggunakan alat SEM-EDXS seperti diperlihatkan pada gambar 5. 
Budiarto Djono Siswanto, Pengaruh Temperatur Artificial Age Terhadap Kekerasan ...
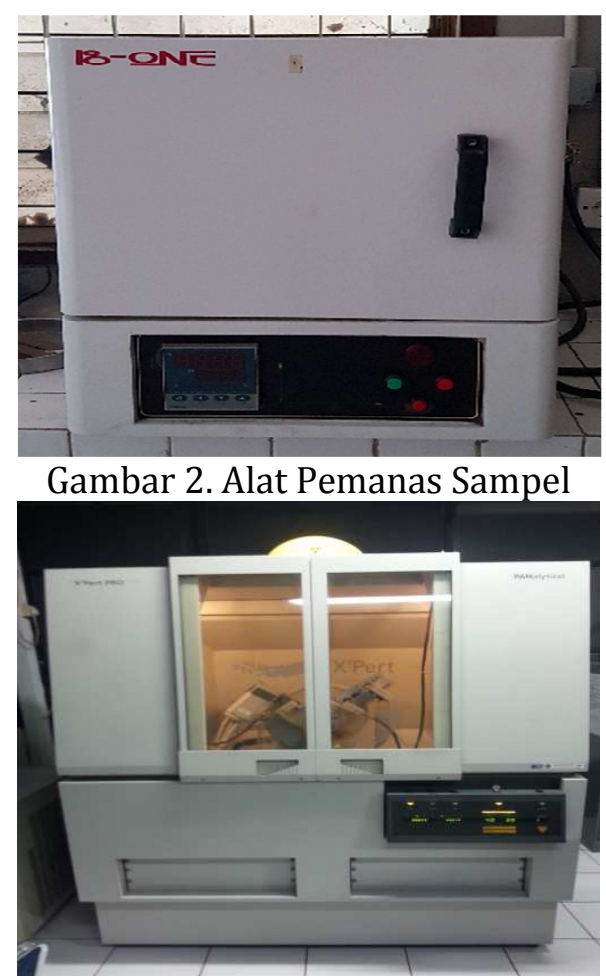

Gambar 3. Alat Difraktometer Sinar-X

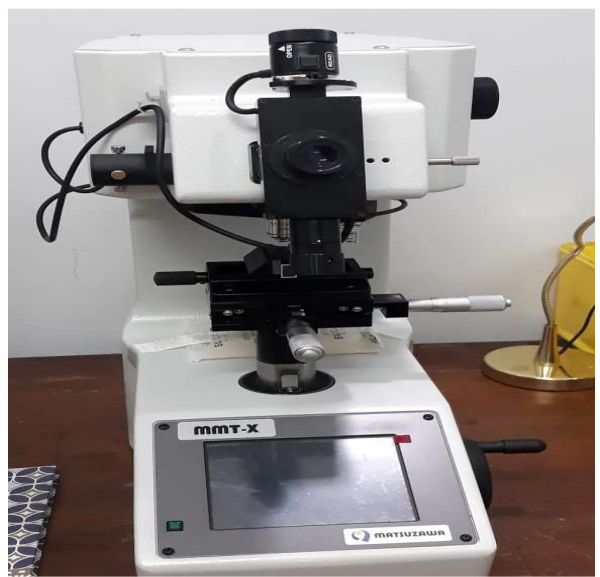

Gambar 4. Alat Uji Kekerasan Skala MikroVickers

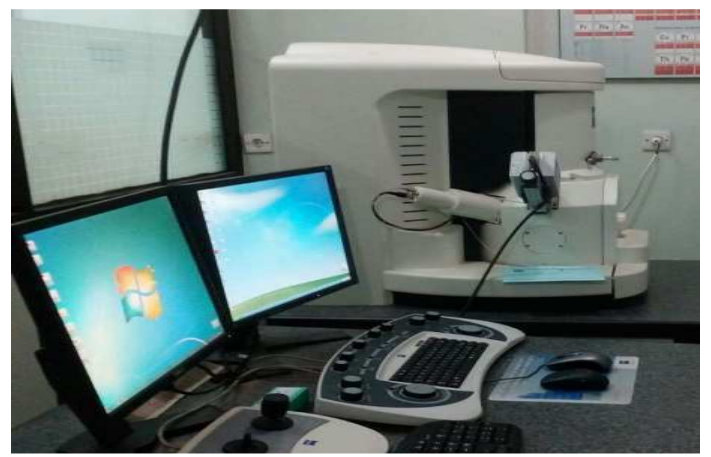

Gambar 5. Alat Scanning Elektron Mikroskop (SEM) 


\section{HASIL DAN PEMBAHASAN}

Analisa kerapatan dislokasi, regangan mikro kisi, dan ukuran kristal, terhadap variasi temperatur artificial age paduan $\mathrm{Al}_{97,11} \mathrm{Mg}_{1,52} \mathrm{Si}_{0,86} \mathrm{Zn}_{0,51}$

Pada gambar 6, menunjukkan hasil difraktogram sinar-X dari sampel paduan Al97,11Mg1,52Si0,86Zn0,51 setelah mengalami proses artificial age variasi temperatur, terdapat empat puncak difraksi yang datanya dapat dilihat pada Tabel 2 sampai Tabel 5. Dari gambar 7, memperlihatkan bidang indeks Miller (hkl) yaitu (111), (200), (220), dan (311) terhadap ukuran kristal terlihat makin besar temperatur artificial age dan waktu holding time(1jam), menunjukkan bahwa ukuran kristalnya makin kecil( dari 6,3nm menjadi 5,8nm) mulai bidang indeks Miller (111) hingga bidang indeks Miller (311) dari 4,3nm menjadi 4,0 $\mathrm{nm}$.

Data ini menunjukkan bahwa naiknya ukuran kristalit kemungkinan disebabkan oleh terjadinya proses rekristalisasi dan pertumbuhan butir selama penuaan. Hal ini dapat dijelaskan karena adanya regangan mikro kisi, bahwa deformasi plastis paduan Al97,11Mg1,52Si0,86Zn0,51 mayoritas terjadi melalui proses dislokasi slip dan twin. Dengan demikian artificial age yang dikenakan pada bahan paduan Al97,11Mg1,52Si0,86Zn0,51 tidak berubah menjadi regangan butir tetapi menjadi rotasi pada kisi kristal. Dimana pergeseran kisi kristal ini menghasilkan kristalit. Karena perlakuan panas (artificial age) yang kedua menyebabkan terjadinya difusi atom-atom pada batas butir, dimana hal ini ditandai dengan peningkatan ukuran Kristal dibidang indeks Miller (111). Pada Grafik 8, memperlihatkan kerapatan dislokasi terlihat makin besar, dengan temperatur artificial age, makin besar yaitu 0,028 garis/mm2 pada bidang indeks Miller (111) menjadi 0,058 garis/mm2 pada bidang indeks Miller (311). Hal ini berarti makin besar temperatur artificial age makin banyak cacat garisnya pada bidang indeks Miller (311). 
Budiarto Djono Siswanto, Pengaruh Temperatur Artificial Age Terhadap Kekerasan ...

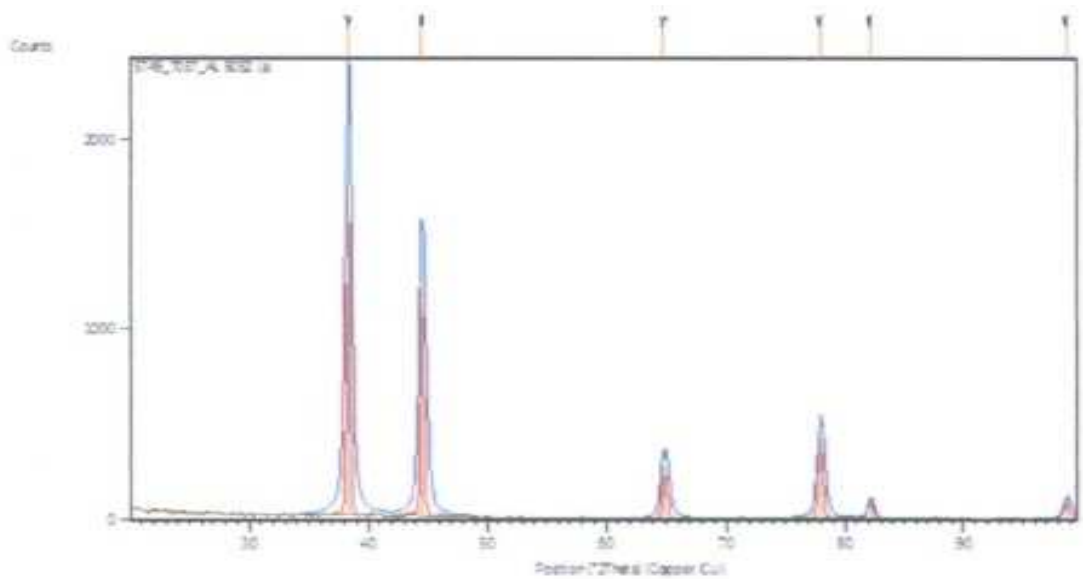

(a)

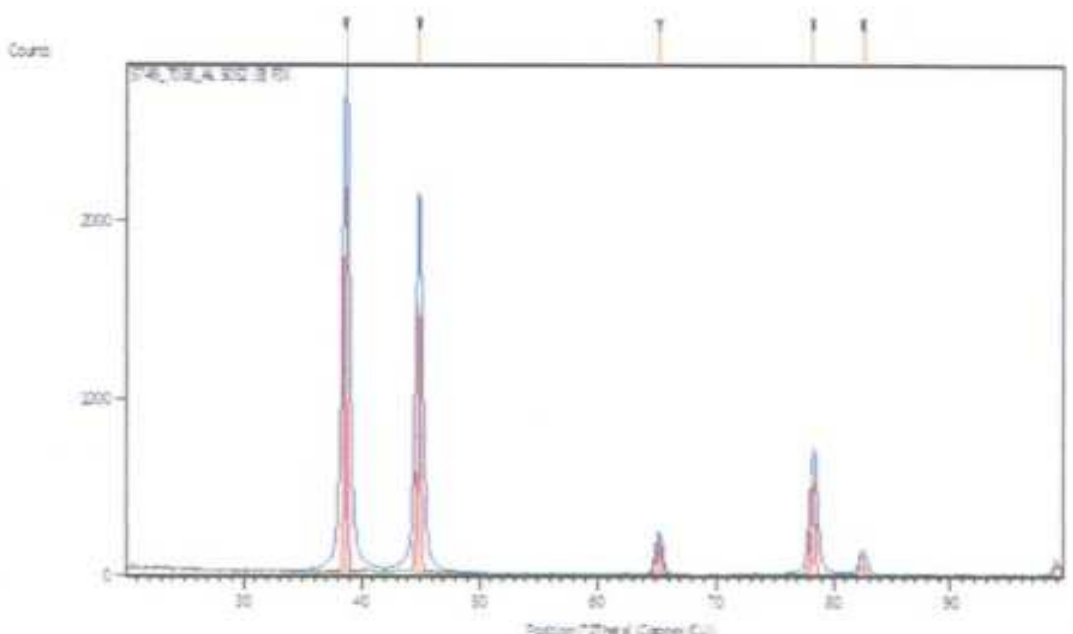

(b)

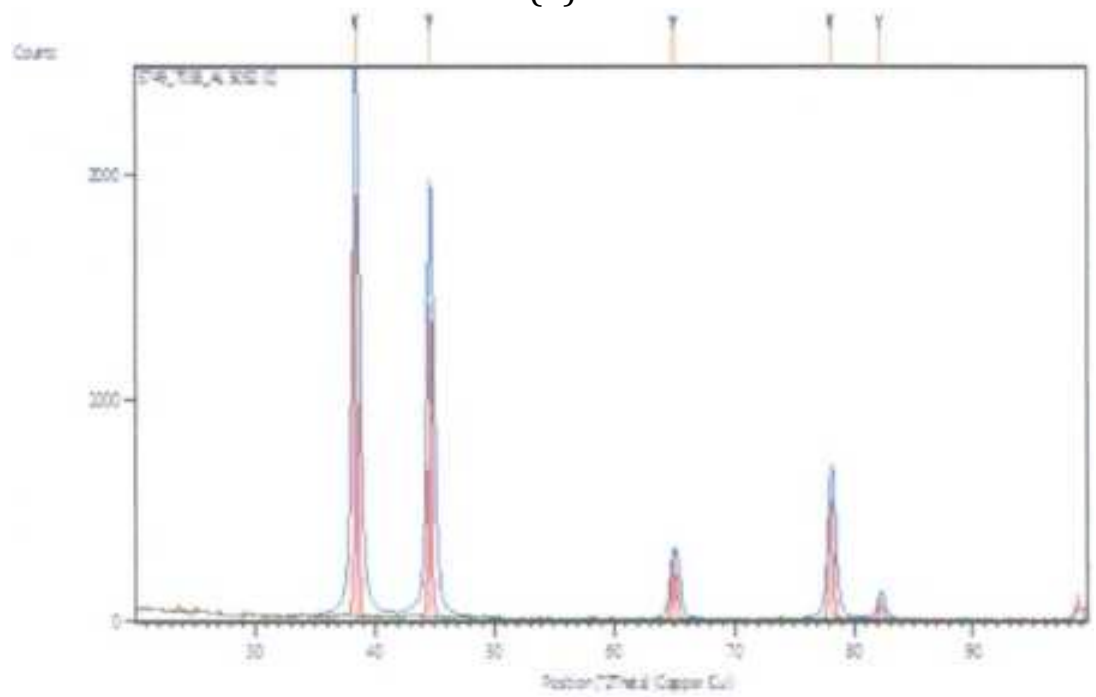

(c)

Gambar. 6. Difraktogram sinar-x dari paduan $\mathrm{Al}_{97,11} \mathrm{Mg}_{1,52} \mathrm{Si}_{0,86} \mathrm{Zn}_{0,51}$ waktu artificial age tetap 1 jam dan variasi temperatur a). $140^{\circ} \mathrm{C}$, b) $170^{\circ} \mathrm{C}$, dan c). $200^{\circ} \mathrm{C}$. 
Tabel 2. Puncak difraksi sinar-X dari paduan $\mathrm{Al}_{97,11} \mathrm{Mg}_{1,52} \mathrm{Si}_{0,86} \mathrm{Zn}_{0,51}$ artificial age waktu 1 jam, variasi temperatur $140{ }^{\circ} \mathrm{C}$

\begin{tabular}{ccccccc}
\hline $\begin{array}{c}\text { PEAK } \\
\text { NO }\end{array}$ & $\begin{array}{c}\mathbf{2} \boldsymbol{\theta} \\
\mathbf{( d e g )}\end{array}$ & $\begin{array}{c}\mathbf{D} \\
\mathbf{( A )}\end{array}$ & $I^{\prime} / I_{o}$ & $\begin{array}{c}\text { FWHM } \\
\mathbf{( d e g )}\end{array}$ & JCPDS & (h k l) \\
\hline 1 & 38,33 & 1,9579 & 100 & 0,150 & Fasa $\alpha-A l$ & 111 \\
2 & 44,57 & 1,6244 & 78 & 0,180 & Fasa $\alpha-A l$ & 200 \\
3 & 64,87 & 1,9727 & 46 & 0,250 & Fasa $\alpha-A l$ & 220 \\
4 & 77,96 & 1,2938 & 64 & 0,160 & Fasa $\alpha-A l$ & 311 \\
\hline
\end{tabular}

Tabel 3. Puncak difraksi sinar-X dari paduan $\mathrm{Al}_{97,11} \mathrm{Mg}_{1,52} \mathrm{Si}_{0,86} \mathrm{Zn}_{0,51}$ artificial age waktu 1 jam, variasi temperatur $170{ }^{\circ} \mathrm{C}$

\begin{tabular}{ccccccc}
\hline $\begin{array}{c}\text { PEAK } \\
\text { NO }\end{array}$ & $\begin{array}{c}\mathbf{2} \boldsymbol{\theta} \\
\mathbf{( d e g )}\end{array}$ & $\begin{array}{c}\mathbf{D} \\
\mathbf{( \AA )}\end{array}$ & $I^{\prime} / I_{o}$ & $\begin{array}{c}\text { FWHM } \\
\text { (deg) }\end{array}$ & JCPDS & (h k l) \\
\hline 1 & 38,64 & 1,9173 & 100 & 0,1420 & Fasa $\alpha-A l$ & 111 \\
2 & 44,88 & 1,7727 & 77 & 0,1504 & Fasa $\alpha-A l$ & 200 \\
3 & 65,19 & 1,9898 & 43 & 0,2701 & Fasa $\alpha-A l$ & 220 \\
4 & 78,26 & 1,3927 & 62 & 0,1806 & Fasa $\alpha-A l$ & 311 \\
\hline
\end{tabular}

Tabel 4. Puncak difraksi sinar-X dari paduan $\mathrm{Al}_{97,11} \mathrm{Mg}_{1,52} \mathrm{Si}_{0,86} \mathrm{Zn}_{0,51}$ artificial age waktu 1 jam, variasi temperatur $200{ }^{\circ} \mathrm{C}$

\begin{tabular}{ccccccc}
\hline $\begin{array}{c}\text { PEAK } \\
\text { NO }\end{array}$ & $\begin{array}{c}\mathbf{2} \boldsymbol{\theta} \\
\mathbf{( d e g )}\end{array}$ & $\begin{array}{c}\text { D } \\
(\AA)\end{array}$ & $I / I_{o}$ & $\begin{array}{c}\text { FWHM } \\
\text { (deg) }\end{array}$ & JCPDS & (h k l) \\
\hline 1 & 38,46 & 1,9259 & 100 & 0,1609 & Fasa $\alpha-A l$ & 111 \\
2 & 44,69 & 1,6332 & 79 & 0,1801 & Fasa $\alpha-A l$ & 200 \\
3 & 65,04 & 1,9666 & 45 & 0,2504 & Fasa $\alpha-A l$ & 220 \\
4 & 78,11 & 1,2943 & 68 & 0,1902 & Fasa $\alpha-A l$ & 311 \\
\hline
\end{tabular}

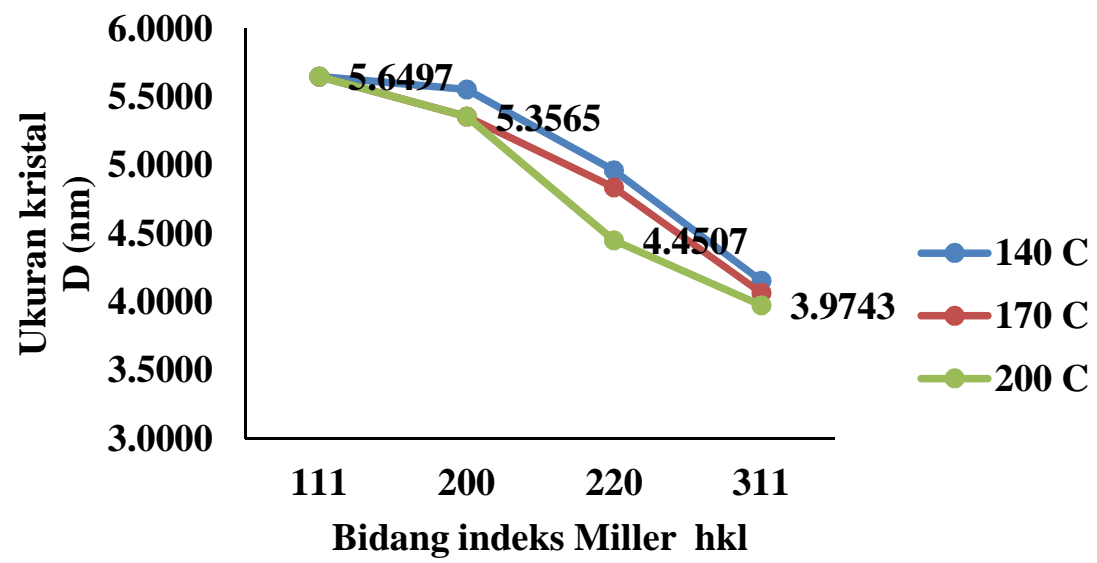

Gambar 7. Grafik Hubungan ukuran kristal terhadap bidang indeks Miller (111), (200), (220), (311). Variasi temperatur penuuan buatan 140,170 , Dan $200{ }^{\circ} \mathrm{C}$ waktu 1 jam. 
Budiarto Djono Siswanto, Pengaruh Temperatur Artificial Age Terhadap Kekerasan ...

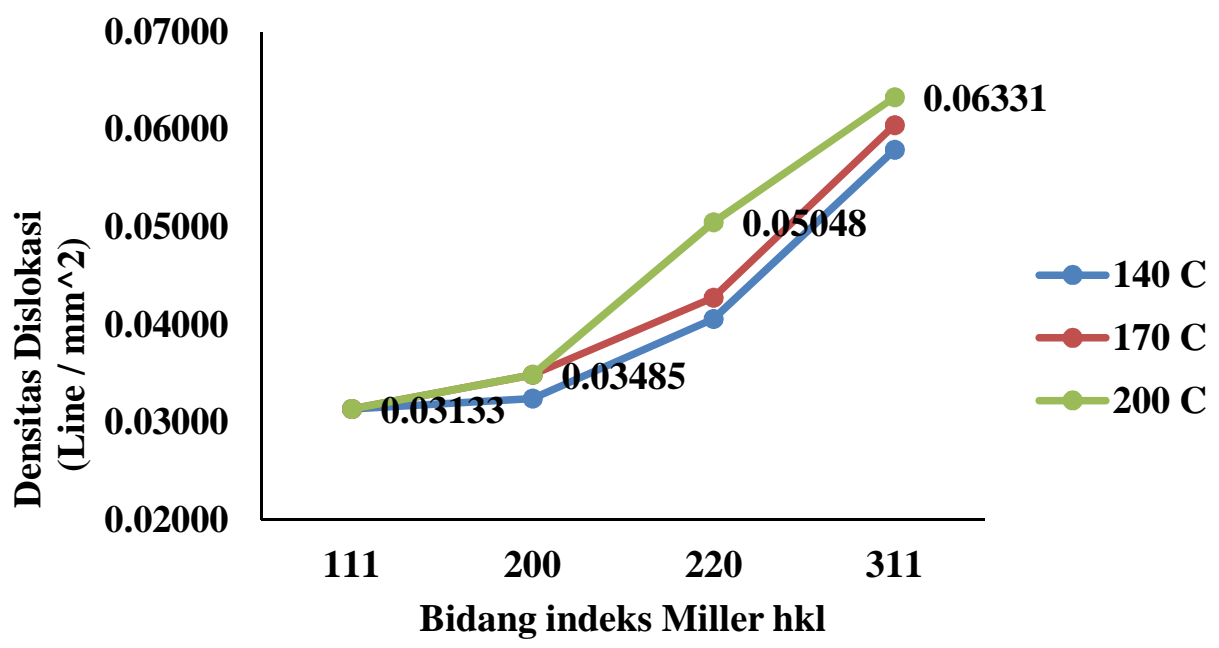

Gambar 8. Grafik Hubungan kerapatan dislokasi terhadap bidang indeks Miller (111), (200),(220),(311).Temperatur artificial age 140,170, dan $200^{\circ} \mathrm{C}$ waktu 1 jam.

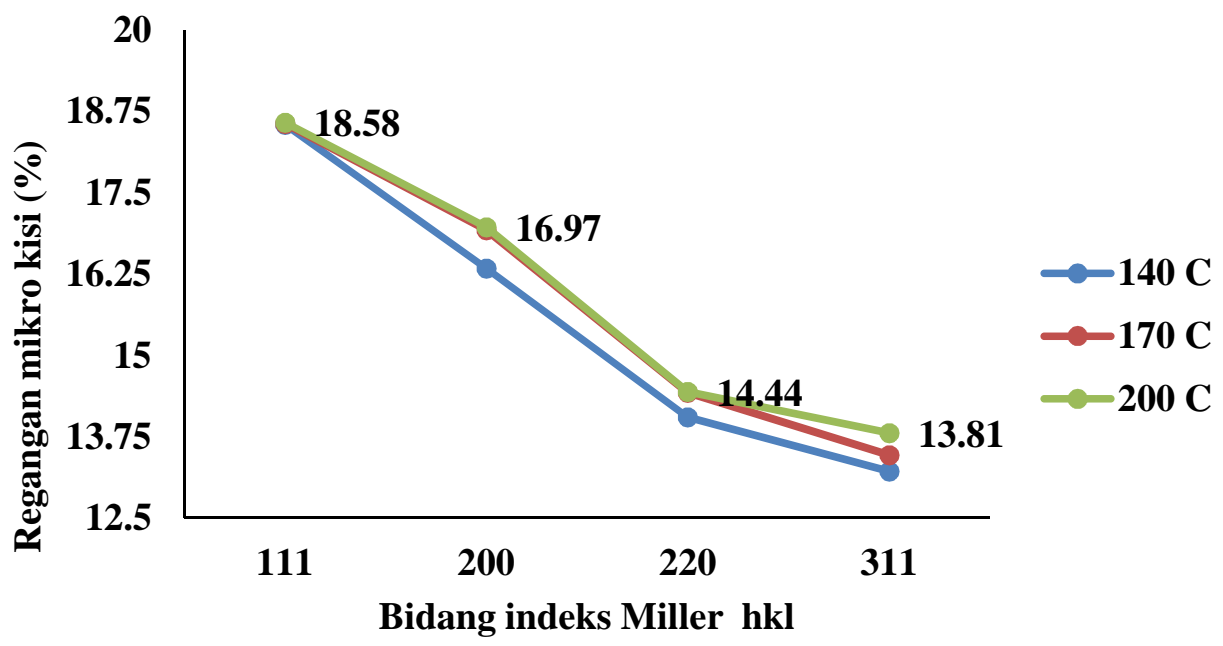

Gambar 9. Grafik Hubungan regangan mikro kisi terhadap bidang indeks Miller (111), (200),(220), (311).Temperatur artificial age 140, 170, Dan $200{ }^{\circ} \mathrm{C}$, waktu 1 jam.

Tabel 5. Nilai Kerapatan dislokasi, Kekuatan luluh, Regangan mikro, Ukuran kristalit dari Paduan $\mathrm{Al}_{97,11} \mathrm{Mg}_{1,52} \mathrm{Si}_{0,86} \mathrm{Zn}_{0,51}$

\begin{tabular}{|c|c|c|c|c|}
\hline $\begin{array}{c}\text { Paduan } \\
\text { Al97,11Mg }_{1,52} \mathrm{Si}_{0,86} \mathrm{Zn}_{0,51}\end{array}$ & $\begin{array}{c}\text { Kerapatan } \\
\text { Dislokasi, } \\
\rho\left(1 / \mathrm{mm}^{2}\right)\end{array}$ & $\begin{array}{c}\text { Kekuatan } \\
\text { Luluh , } \\
\text { Ys (MPa) }\end{array}$ & $\begin{array}{c}\text { Regangan } \\
\text { Mikro, } \\
\text { E (\%) }\end{array}$ & $\begin{array}{c}\text { Ukuran } \\
\text { Kristalit, } \\
\text { D (nm) }\end{array}$ \\
\hline Tempera & 0,0624 & 573,54 & 23,76 & 7,6734 \\
\hline Temperatur $170^{\circ} \mathrm{C}$ & 0,0436 & 354,89 & 19,47 & 8,1342 \\
\hline Temperatur $200^{\circ} \mathrm{C}$ & 0.0067 & 312,65 & 8,64 & 21,3354 \\
\hline
\end{tabular}


Pada Grafik 9, terdapat 4 puncak difraksi dari hasil XRD menunjukkan bahwa paduan $\mathrm{Al}_{97,11} \mathrm{Mg}_{1,52} \mathrm{Si}_{0,86} \mathrm{Zn}_{0,51}$ yang terdiri dari bidang indeks Miller yaitu (111), (200), (220), dan (311) terhadap regangan mikro kisi terlihat makin besar temperatur artificial age, nilai regangan mikro kisi sama besarnya di bidang indeks Miller (111) yaitu 18,5\%. Demikian pula pada bidang indeks Miller (311) terlihat makin besar temperatur artificial age, nilai regangan mikro kisi makin kecil yaitu 3,75 \%. Dari gambar 7,8 dan 9,menunjukkan grafik bahwa peningkatan temperatur pada perlakuan panas artificial age mengakibatkan penyempitan puncak difraksi, dimana ditandai dengan penurunan nilai FWHM. Hasil tersebut mengungkapkan bahwa terjadi pertumbuhan butir dari paduan terlihat makin besar temperatur artificial age, makin besar kerapatan dislokasinya. Data ini menunjukkan bahwa rendahnya regangan mikro kisi kemungkinan terjadinya proses rekristalisasi dan pertumbuhan butir selama artificial age. Berdasarkan data dari peneliti terdahulu bahwa kerapatan dislokasi hasil dari artificial age dibidang indeks Miller (311) lebih besar dibandingkan dengan bidang indeks Miller (111), berarti ada batas regangan maksimum akibat deformasi. Regangan mikro maksimum disebabkan oleh mekanisme deformasi dan harus memenuhi konstansi rasio c/a, sehingga kerapatan dislokasi menjadi bertambah. Penambahan kerapatan dislokasi mengakibatkan naiknya tegangan sisa yang selanjutnya pada kekuatan luluh $[12,13]$.

Selain itu, pola difraktogram juga menunjukkan bahwa intensitas dari puncak difraksi meningkat dengan meningkatnya temperatur artificial age saat perlakuan panas. Ini mengindikasikan bahwa terjadi peningkatan kualitas kristal dari paduan $\mathrm{Al}_{97,11} \mathrm{Mg}_{1,52} \mathrm{Si}_{0,86} \mathrm{Zn}_{0,51}$, terlihat makin besar temperatur artificial agenya, makin kecil nilai kerapatan dislokasinya, hal ini salah satunya dipengaruhi oleh regangan mikro kisi. Untuk itu dengan regangan mikro kisi dan kerapatan dislokasi yang rendah mengindikasikan kualitas kristal yang baik. Hasil tersebut berkaitan erat dengan berkurangnya cacat kristal bentuk garis(dislokasi). Karena peningkatan cacat kristal bentuk garis ditunjukkan dengan meningkatnya nilai regangan mikro kisi yang berakibat pada peningkatan kerapatan dislokasi. Karena regangan mikro kisi mempengaruhi panjang garis dislokasi per satuan volume kristal $[12,13]$. 
Budiarto Djono Siswanto, Pengaruh Temperatur Artificial Age Terhadap Kekerasan ...

Analisa kekerasan terhadap variasi temperatur artificial age paduan Al97,11 Mg

Hasil pengujian dengan skala Vicker mengacu pada ASTM E92, terlihat adanya kenaikan nilai kekerasan sebelum dan sesudah perlakuan panas T6 dan artificial age dengan variasi temperature seperti diperlihatkan pada tabel 6.

\begin{tabular}{cc} 
Tabel 6. Hasil uji kekerasan paduan $\mathrm{Al}_{97,11} \mathrm{Mg}_{1,52} \mathrm{Si}_{0,86} \mathrm{Zn}_{0,51}$ \\
\hline $\begin{array}{c}\text { Kekerasan } \\
\text { (HV) }\end{array}$ \\
\hline Asli & 54 \\
Solid solution $530^{\circ} \mathrm{C}$ dan Quenching & 75 \\
dimedia air es & \\
Artificial age temperatur $140^{\circ} \mathrm{C}$ & 82 \\
Artificial age temperatur $170^{\circ} \mathrm{C}$ & 87 \\
Artificial age temperatur $200^{\circ} \mathrm{C}$ & 94
\end{tabular}

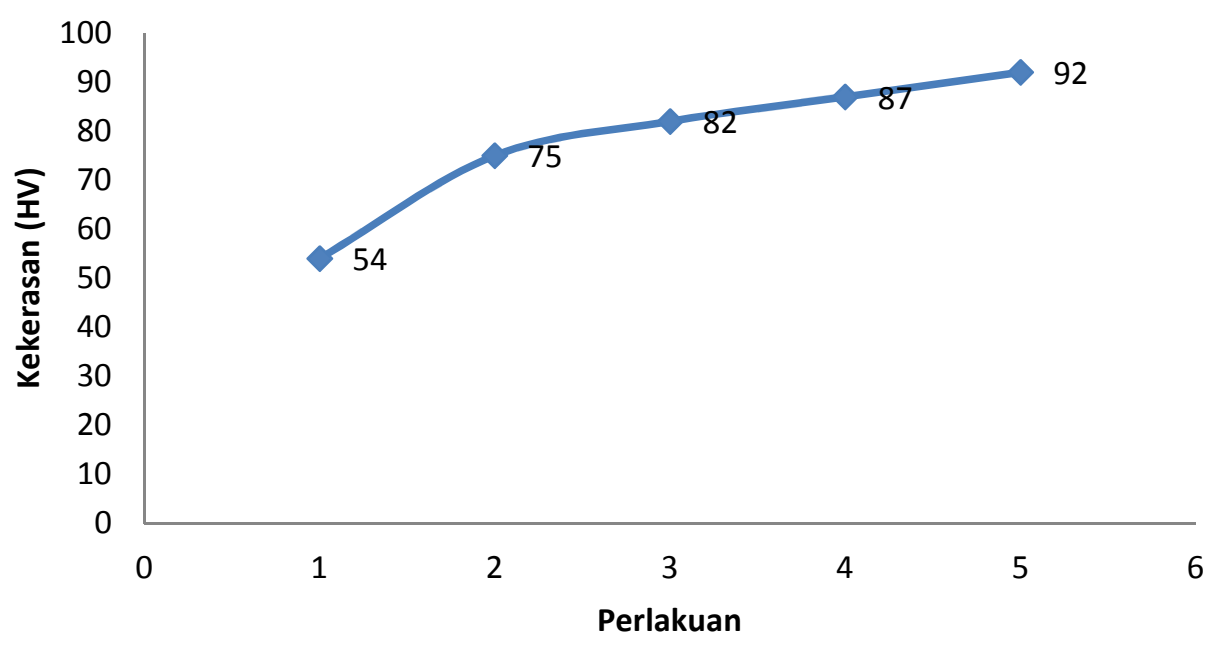

Gambar 10. Hubungan nilai kekerasan terhadap kondisi uji pada paduan $\mathrm{Al}_{97,11} \mathrm{Mg}_{1,52} \mathrm{Si}_{0,86} \mathrm{Zn}_{0,51}:$ 1) as cast, 2) Proses T6 dan temperatur Artificially age, 3) 140 ${ }^{\circ} \mathrm{C}$, 4) $170{ }^{\circ} \mathrm{C}$, dan 5) $200{ }^{\circ} \mathrm{C}$

Sampel paduan $\mathrm{Al}_{97,11} \mathrm{Mg}_{1,52} \mathrm{Si}_{0,86} \mathrm{Zn}_{0,51}$ sebelum perlakuan panas $\mathrm{T} 6$ nilai kekerasannya (as cast) $54 \mathrm{HV}$ (Tabel 6). Setelah diberi perlakuan panas solid solution pada $530{ }^{\circ} \mathrm{C}$, selama 1 jam kemudian di quenching media air es nilai kekerasan adalah $75 \mathrm{HV}$. Setelah proses artificially age pada 140,170, dan $200{ }^{\circ} \mathrm{C}$ waktu tahan 1 jam terjadi kenaikan nilai kekerasan yang signifikan yaitu 82-94 HV seperti diperlihatkan pada gambar 10. Hal ini disebabkan pada paduan $\mathrm{Al}_{97,11} \mathrm{Mg}_{1,52} \mathrm{Si}_{0,86} \mathrm{Zn}_{0,51}$ telah terbentuk fasa $\mathrm{Mg}_{2} \mathrm{Si}$ yang menyebar merata baik di batas butir maupun di matriknya fasa $\alpha$-Al. Meningkatnya kekerasan tersebut disebabkan karena fasa $\mathrm{Mg}_{2} \mathrm{Si}$ memasuki tempat 
diantara atom-atom Aluminium (lattice kristal) sehingga susunan atom akan menjadi lebih rapat dan menimbulkan ikatan yang semakin kuat. Gaya yang diperlukan untuk menimbulkan dislokasi semakin besar, yang berarti kekerasan semakin besar. Namun paduan $\mathrm{Al}_{97,11} \mathrm{Mg}_{1,52} \mathrm{Si}_{0,86} \mathrm{Zn}_{0,51}$ mempunyai kekerasan harga maksimum, apabila telah melebihi batas kelarutannya, tetapi fasa $\mathrm{Mg}_{2}$ Si yang terbentuk akan memperlemah ikatan antar atom. Sehingga gaya yang diperlukan untuk mendeformasi/merusak akan semakin kecil, yang berarti menurunkan kekerasan [14].

\section{Analisa hasil pengamatan struktur mikro}

Hasil pengamatan morfologi permukaan dengan SEM-EDX diperlihatkan pada gambar 11, 12, dan 13. Dari Gambar 11, paduan $\mathrm{Al}_{97,11} \mathrm{Mg}_{1,52} \mathrm{Si}_{0,86} \mathrm{Zn}_{0,51}$ menunjukkan bahwa semakin besar temperatur pemanasan maka bintik bintik putih akan semakin besar dan menyebar merata. Dengan adanya Mg yang membentuk senyawa $\mathrm{MgSi}_{2}$ yang tersebar merata maka akan menghambat terjadinya dislokasi bila ada gaya dari luar, atau dengan kata lain gaya yang diperlukan untuk mendeformasi/merusak akan semakin besar, yang berarti kekerasan akan semakin besar. Nilai kekerasan, pada kondisi perlakuan panas T6 selalu lebih besar dari pada kondisi as-cast. Hal ini disebabkan karena jumlah presipitat sebagai fasa $\mathrm{Mg}_{2} \mathrm{Si}$ yang terlarut dalam paduan $\mathrm{Al}_{97,11} \mathrm{Mg}_{1,52} \mathrm{Si}_{0,86} \mathrm{Zn}_{0,51}$ akan semakin besar karena kemampuan untuk mengandung presipitat sebagai fasa $\mathrm{Mg}_{2} \mathrm{Si}$ meningkat setelah diberi perlakuan panas.Disamping itu juga disebabkan karena, dengan adanya perlakuan panas T6 maka bentuk butiran berubah dari bentuk bulat menjadi lonjong. Bentuk butiran yang lonjong menyebabkan gaya yang diperlukan untuk mendeformasi akan semakin besar dibandingkan dengan bentuk butiran yang bulat [15, 16].

Dari gambar 11 sampai 13, menunjukkan bahwa mikrograf dari paduan Al97,11Mg1,52Si0,86Zn0,51, setelah penuaan bantuan dengan variasi temperature 140 0C, 170 0C, dan 200 0C, waktu 1 jam. Terlihat semuanya berbentuk equaxial pada kondisi temperatur 140 0C, 170 0C, dan 200 0C serta waktu 1 jam. Butir hasil artificial age menunjukkan elongated grain. Berubah bentuk butir setelah artificial age ini akibat deformasi sehingga 200 OC mengubah bentuk butiran bahan paduan Al97,11Mg1,52Si0,86Zn0,51. Hal ini juga akan berdampak pada sifat mekanik yaitu kekerasan yang dihasilkan. 


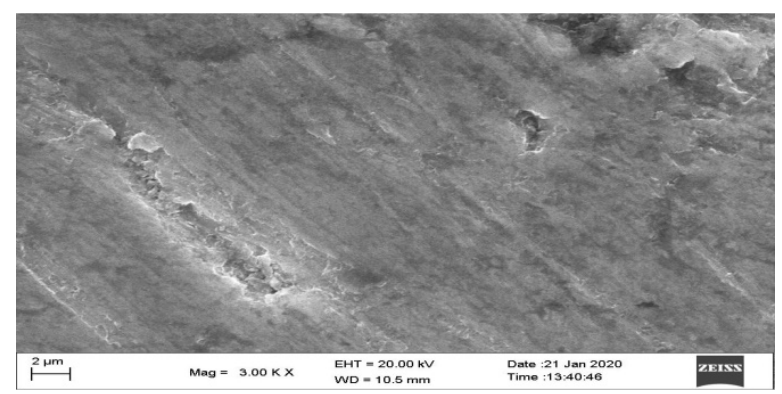

Gambar 11. Mikrograf dari paduan $\mathrm{Al}_{97,11} \mathrm{Mg}_{1,52} \mathrm{Si}_{0,86} \mathrm{Zn}_{0,51}$, Artificial age temperatur $140{ }^{\circ} \mathrm{C}$, pembesaran $3000 \mathrm{X}$

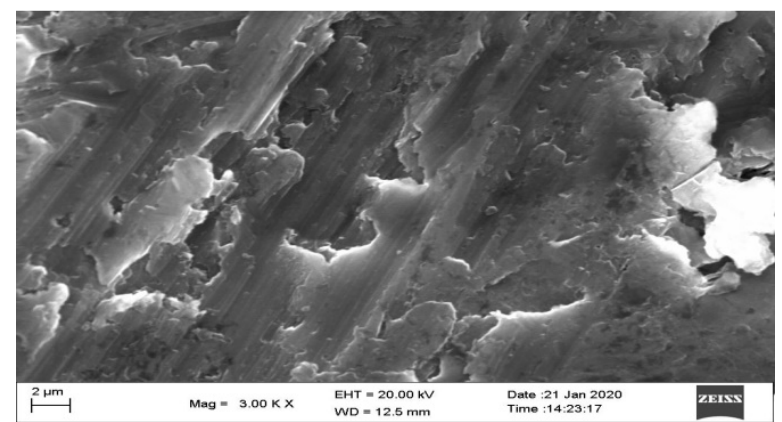

Gambar 12. Mikrograf dari paduan $\mathrm{Al}_{97,11} \mathrm{Mg}_{1,52} \mathrm{Si}_{0,86} \mathrm{Zn}_{0,51}$, Artificial age temperatur $170{ }^{\circ} \mathrm{C}$, pembesaran $3000 \mathrm{X}$

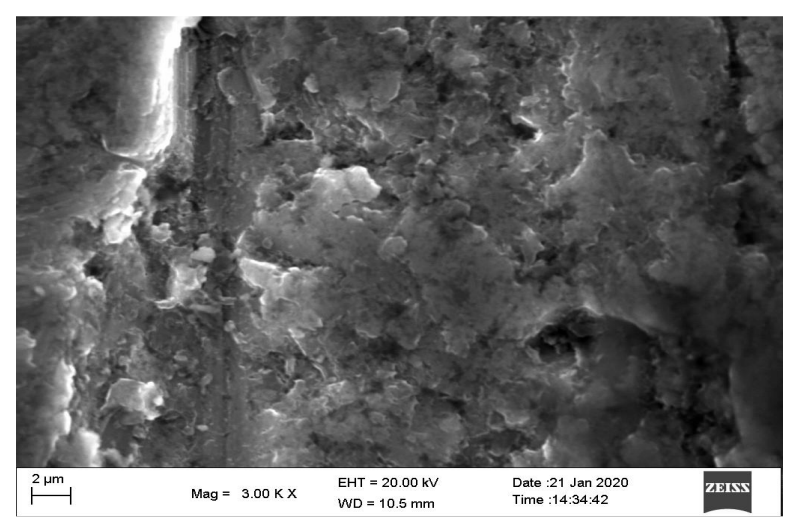

Gambar 13. Mikrograf dari paduan $\mathrm{Al}_{97,11} \mathrm{Mg}_{1,52} \mathrm{Si}_{0,86} \mathrm{Zn}_{0,51}$, Artificial age temperatur $200{ }^{\circ} \mathrm{C}$, pembesaran $3000 \mathrm{X}$

\section{KESIMPULAN}

Paduan Al97,11 $\mathrm{Mg}_{1,52} \mathrm{Si}_{0,86} \mathrm{Zn}_{0,51}$ mencapai kekerasan terbesar pada perlakuan panas artificial age pada temperatur $200{ }^{\circ} \mathrm{C}$ dan holding time I jam sebesar 94HV, serta kekerasan terkecilnya artificial aging pada temperatur $140{ }^{\circ} \mathrm{C}$ dan holding time 1 jam sebesar 82HV. Kekuatan luluh pada paduan $\mathrm{Al}_{97,11} \mathrm{Mg}_{1,52} \mathrm{Si}_{0,86} \mathrm{Zn}_{0,51}$ terbesar pada perlakuan panas artificial age pada temperatur $140{ }^{\circ} \mathrm{C}$ dan holding time I jam sebesar $573,54 \mathrm{MPa}$, dan kekuatan luluh terkecilnya terjadi artificial aging pada temperatur 200 ${ }^{\circ} \mathrm{C}$ dan holding time 1 jam sebesar 312,65 MPa. Namun kerapatan dislokasi terbesar pada 
perlakuan panas artificial age pada temperatur $200{ }^{\circ} \mathrm{C}$ dan holding time I jam sebesar $0,06241 / \mathrm{mm}^{2}$, serta kerapatan dislokasi terkecilnya terjadi artificial aging pada temperatur $140{ }^{\circ} \mathrm{C}$ dan holding time 1 jam sebesar $0,0067.1 / \mathrm{mm}^{2}$. Dan regangan mikro terbesar pada perlakuan panas artificial age pada temperatur $140{ }^{\circ} \mathrm{C}$ dan holding time I jam sebesar 23,76\%, serta regangan mikro terkecilnya terjadi artificial aging pada temperatur $200^{\circ} \mathrm{C}$ dan holding time 1 jam sebesar 8,64\%.

\section{UCAPAN TERIMA KASIH}

Terima kasih disampaikan kepada Rektor Universitas Kristen Indonesia yang telah mendanai penelitian ini.

\section{REFERENSI}

[1] T. Surdia dan S. Saito, Pengetahuan Bahan Teknik, Jakarta: Pradnya Paramita, 2005.

[2] C. Jr. dan W. D. , Material Science And Enginering, New Jersey: John Wiley \& Sons, Inc., 1994.

[3] R. . E. Smallman, R. J. Bishop dan S. Djaprie, Metalurgi Fisik Modern dan Rekayasa Material, Jakarta: Erlangga, 200o.

[4] D. P. Putri, J. S. Budiarto dan D. Antonius, "Pengaruh Waktu Artificial Aging terhadap Struktur Kristal Kerapatan Dislokasi dan Kekerasan pada Paduan Al-7075," JMEMME (Journal of Mechanical Enggineering, Manufactures, Materials and Energy), vol. 4, no. 2, pp. 114-128, 2020.

[5] R. Megantara, J. S. Budiarto dan D. Antonius, "Analisis Pengaruh Suhu Artificial Age Terhadap Kekerasan, Densitas Dan Struktur Kristal Paduan Alumunium-5052 Untuk Bahan Sirip Roket," JMEMME (Journal of Mechanical Enggineering, Manufactures, Materials and Energy), vol. 4, no. 2, pp. 129-140, 2020.

[6] A. J. Zulfikar, A. Sofyan dan M. Y. Siahaan, "Numerical Simulation on The Onion Dryer Frame Capacity of 5 kg/hour," JMEMME (Journal of Mechanical Engineering Manufactures Materials and Energy), vol. 2, no. 2, p. 86-92, 2018.

[7] A. J. Zulfikar, B. Umroh, A. Amrinsyah dan F. A. Nasution, "Numerical Analysis of Strength of Rear Brake Holder Flat on The Motor," JMEMME (Journal Of Mechanical Engineering, Manufactures, Materials And, vol. 2, no. 1, pp. 1-6, 2018.

[8] A. J. Zulfikar, "The Flexural Strength of Artificial Laminate Composite Boards made from Banana Stems," Budapest International Research in Exact Sciences (BirEx) Journal, vol. 2, no. 3, pp. 334340, 2020.

[9] M. Y. Yuhazri, A. J. Zulfikar dan A. Ginting, "Fiber Reinforced Polymer Composite as a Strengthening of Concrete Structures: A Review," International Conference in Industry and Manufacture Engineering, vol. 2020, no. 1, pp. 1-13, 2020.

[10] A. J. Zulfikar dan M. Y. R. Siahaan, "Analisis Signifikansi Roda Skateboard Berbahan Komposit Serbuk Batang Pisang Terhadap Perfoma Kecepatan Dengan Metode Anova," Jurnal Rekayasa Material, Manufaktur dan Energi, vol. 4, no. 2, pp. 83-90, 2021.

[11] S. Alfath dan J. S. Budiarto, "Analisis Pengaruh Waktu Artificial Age (T6) Terhadap Struktur Kristal, Densitas dan Kekerasan pada Paduan Al-6o61 Untuk Bahan Sirip Roket," JMEMME (Journal of Mechanical Enggineering, Manufactures, Materials and Energy), vol. 4, no. 2, pp. 102-113, 2020. 
Budiarto Djono Siswanto, Pengaruh Temperatur Artificial Age Terhadap Kekerasan ...

[12] H. Demir dan S. Gunduz, "The effecf of aging on machinability of 6061 Al alloy," Materials and design, vol. 30, no. 2, pp. 80-90, 2009.

[13] K. Kapoor, D. Lahiri, S. V. R. Lahore, T. Sanyal dan B. P. Kashyap, "X-Ray Diffraction Line Profile Analysis for Defect Study in Zr-2.5\%Nb," Material Science, vol. 27, no. 1, pp. 65-73, 2004.

[14] H. H. Kim, S. H. Cho dan C. G. Kang, "Evalution of microstructure and mechanical properties by using nano-micro-indenfation and nanoscratch during aging treatment of rheo-forget Al-6o61 alloy," Materials Science and Engineering, vol. 85, no. 1, pp. 272-281, 2008.

[15] S. Suhariyanto, "Peningkatan Sifat Mekanik Paduan Aluminium A 356.o dengan penambahan TiC dan Perlakuan Panas T6," SAINTEK Jurnal Ilmiah Teknik dan Rekyasa, vol. 8, no. 2, pp. 56-68, 2004 .

[16] P. Aryanto, T. Marwoto, M. Sudiro dan D. Birowosuto, "Structure evolution of zinc oxide thin films deposited by unbalance DC magnetron sputtering," dalam International AIP Conference, Jakarta, 2016. 